\title{
ATTITUDES OF ENGINEERING STUDENTS TOWARDS LEARNING COMMUNICATION SKILLS: A STUDY
}

\author{
Dr. Dipakkumar A. Bhatt
}

\begin{abstract}
Communication Skills play a very significant role in the life an engineering graduate. It is important for an engineering student to have command on communication skills, keeping in mind the present job scenario demands of the recruiters. The aim of the present study is to find out the attitude of the engineering students towards learning the subject of communication skills in their $2^{\text {nd }}$ year of engineering named Effective Technical Communication. A comparative study was conducted between English medium students' and vernacular medium-Gujarati medium students' approach towards learning communication skills subject. Likert Scale questionnaire having 10 statements was designed and it was surveyed from two universities of the State teaching B.E./B.Tech. programs. A total number of 26 respondents' responses were analyzed using one-tailed t-test and the p-value was utilized to justify the alternative hypothesis. It has been noticed that the students keep positive approach towards learning the subject, though few students hold negative attitude for learning the subject. It seems necessary to mention that the fact is realized by the students that strengthening the communication skills can have positive impact on their future prospects.
\end{abstract}

Keywords:- Communication Skills, Likert Scale, t-test

\section{Introduction}

Engineering students need to have a good command on the communication skills as they play a very important role in their personal and professional life. Communication Skills are one of the engineering attributes out of the 12 attributes laid by National Board of Accreditation (NBA) for successful engineering graduate. A good amount of research work has been done in the country and state to say that engineering graduates hold poor communication skills. Therefore the present study was conducted to assess whether the engineering students have a positive or negative attitude towards learning the subject of communication skills.

Tanyel and Mitchell strongly administered that the communication abilities required in the professional world include presentation, cultural awareness and interpersonal communication skills, written and oral communication, and team skills (p. 33-38). Pollack-Wahl mentioned that oral and presentation skills are must for having sound professional careers for 
engineering students (p. 16-21). Rees and Garrud reported that grown-up students had high positive attitudes towards communication skills training (p. 23). Marc J. Rimer talks about the need and importance of communication skills for engineering graduates in their professional lives. He also mentions that lack of communication skills can also hamper the image of the engineering graduates in the job market (p. 91-99).

Bernd Schulz stresses the need of soft skills that contribute to the hard skills of the technical persons. The author also suggest that students require a good amount of soft skills besides technical skills, which are mainly communication skills, problem solving skills, critical and structured thinking, self-esteem, empathy, creativity, business management, and many other skills connected with personal traits. The importance of oral and written skills in English is ignored over the period of time and therefore we see engineers with good knowledge of technical skills but very poor communication skills (p. 146-154).

V. Saravanan points out the need of employability skills and the need of inclusion of soft skills in the school curricula. If employability skills will enhance, it will create positive impact on the job market (p. 1-9). Chung, Yoonsook, Yoo, Jungskook, Kim, Sung-Won, Lee, Hyunju and Zeidler, Dana L. elaborate on the demand of communication skills in the $21^{\text {st }}$ century. They also stress the importance of peer interactions, and stimulating students' reasoning (p. 2-27). Hamid, Roszilah \& Kamaruzaman, Fathiyah Mohd point out the requirement of new skills required with the advancement of technology. With the present scenario in the field of recruitment new skills are required by the engineering aspirants, which are analytical thinking, creativity, originality, active learning, learning strategies, technology design, programming, critical thinking, emotional intelligence, system analysis, and evaluation. It is also pointed out that these skills can help the engineering students get better job opportunities in future (p.15-28).

\section{Aim of the Study}

The aim of the present study is to find out the attitude/s of the engineering students towards learning communication skills through the course offered by the universities, i.e. Effective Technical Communication

\section{Hypothesis}

Ho Vernacular medium school background students have different attitude towards learning communication skills as compared to English medium students' attitude. 
$\mathrm{H}_{\mathrm{a}}$ Vernacular medium school background students don't have different attitude towards learning communication skills as compared to English medium students' attitude.

\section{Methodology and Results}

The main idea behind the study was to compare the English medium students' attitude for learning communication skills with that of the vernacular medium school background. Keeping the aim in mind, the following research questions were framed:

(i) Do the engineering students consider learning communication skills important for their career or not?

(ii) Are there any attitude difference between the English medium and vernacular medium school background students towards learning communication skills?

The respondents included 26 engineering students from two different universities in the State of Gujarat and in the city of Ahmedabad namely Gujarat Technological University and Silver Oak University offering B.E./B.Tech. programs. The subject Effective Communication Skills is offered to both the universities' students and the academic year of data collection was 2020-2021.

A five-point Likert Scale questionnaire (Agree, Strongly Agree, Neutral, Disagree, and Strongly Disagree) with ten statements on them was prepared and surveyed among these respondents. Their responses were analyzed using the statistical method of one-tailed t-test. The calculations of the t-test were done using the Microsoft excel features of data analysis. Following is the analysis of the questionnaire with p-value which is more than the one-tailed t-test standard .05 , which means the null hypothesis is rejected and the alternative hypothesis is accepted. 
Table.1 P value of one-tailed t-test for each Likert Scale questionnaire item

\begin{tabular}{|c|c|c|}
\hline $\begin{array}{l}\text { Sr. } \\
\text { No. }\end{array}$ & Likert Scale Questionnaire Statement & P-value \\
\hline 1 & $\begin{array}{l}\text { For becoming a successful engineer, communication skills are very } \\
\text { important for me. }\end{array}$ & 0.5 \\
\hline 2 & $\begin{array}{l}\text { I feel that some part of the present syllabus of Effective Communication } \\
\text { Skills subject should be taught at 3rd or 4th year of engineering like } \\
\text { presentation skills, group discussion skills, public speaking skills, } \\
\text { critical and creative thinking skills, etc. as we need them the most } \\
\text { before our placement activities start. }\end{array}$ & 0.450493 \\
\hline 3 & $\begin{array}{l}\text { According to me, both communication skills and soft skills are equally } \\
\text { important. }\end{array}$ & 0.349244 \\
\hline 4 & Effective Technical Communication is an unnecessary course. & 0.403775 \\
\hline 5 & $\begin{array}{l}\text { Learning ethical values is important for me as an engineer, and I } \\
\text { appreciate it as being part of the ETC (Effective Technical } \\
\text { Communication) course. }\end{array}$ & 0.295876 \\
\hline 6 & $\begin{array}{l}\text { I feel self-development and self-assessment are necessary in syllabus as } \\
\text { they comprise of the } 12^{\text {th }} \text { Program Outcomes of engineering attributes } \\
\text { for a successful engineer, mandated by National Board of Accreditation } \\
\text { (NBA). }\end{array}$ & 0.382149 \\
\hline 7 & $\begin{array}{l}\text { Telephonic etiquettes are one of the necessary skills for oral } \\
\text { communication skills. }\end{array}$ & 0.385292 \\
\hline 8 & $\begin{array}{l}\text { Interview skills are more important to study in the later semesters and } \\
\text { not now as these are important skills from placement point of view. }\end{array}$ & 0.451663 \\
\hline 9 & $\begin{array}{l}\text { I need to increase my hours of practicing Listening, Speaking, Reading, } \\
\text { Writing (LSRW) skills to master these skills in English. }\end{array}$ & 0.476244 \\
\hline 10 & Technology is very much useful in learning communication skills. & 0.5 \\
\hline
\end{tabular}

\section{Discussion}

As it is apparent that all the p-values in the above table are higher than .05, it means that there is no difference in the attitudes of the two types of learners towards learning communication skills for their professional and academic careers. Though there is no difference between the English medium and vernacular medium school background students in the way they give 
importance to learning communication skills, it has been noticed that a few students learn communication skills due to certain specific reasons. This has been brought to notice with statement number 4, "Effective Technical Communication is an unnecessary course." Few respondents chose to be neutral in their response, which leads to believe that they have some special purpose of studying communication skills. The agreement on statement 8 "Interview skills are more important to study in the later semesters and not now as these are important skills from placement point of view" by majority of the students shows that interview skills need to be taught in the final-year or pre-final year of engineering as they are required the most by the students at that point of time when they are expecting recruitment or undergoing it. All the learners realize the need of communication at the same level which is approved by statement number 1, "For becoming a successful engineer, communication skills are very important for me." Statement 3 "According to me, both communication skills and soft skills are equally important" focuses on the need of both soft skills and technical skills for the learners. The need of ethical values is approved by statement number 5 "Learning ethical values is important for me as an engineer, and I appreciate it as being part of the ETC (Effective Technical Communication) course.” An engineering attribute of self-development and assessment is also stressed positively by the respondents through questionnaire statement number 6 "I feel self-development and self-assessment are necessary in syllabus as they comprise of the $12^{\text {th }}$ Program Outcomes of engineering attributes for a successful engineer, mandated by National Board of Accreditation (NBA)." Telephonic skills and need for more practice of LSRW skills are affirmed through statements numbers 7 and 9, besides the use of technology for learning communication skills exhibited by statement 10 "Technology is very much useful in learning communication skills".

\section{Conclusion}

For achieving success in job market, communication skills are of utmost importance. The learners irrespective of their medium of school background realize the need to learn communication skills. The need of communication skills and soft skills has boosted the learners to learn the subject of communication skills in much better way. It is also stressed that the faculty teaching engineering subjects must teach the learners in English language so as to help the learners strengthen their English language in content areas. The faculty of English also should boost the learners to sharpen their communication for better future prospects. 


\section{Works Cited}

Chung, Yoonsook, Yoo, Jungskook, Kim, Sung-Won, Lee, Hyunju and Zeidler, Dana L.

"Enhancing Students' Communication Skills in the Science Classroom through Socioscientific Issues." International Journal of Science and Mathematics Education, Ministry of Science and Technology, Taiwan. 2014.

Hamid, Roszilah \& Kamaruzaman, Fathiyah Mohd. "Comparison of Engineering Skills with 4.0 Skills. Malaysia.” M.S. Rasul Universiti Kebangsaan. 2019.

Marc J. Riemer. "English and Communication Skills for the Global Engineer." Global Journal of Engineering Education. 2012. 6 (1): pp.91-99.

Pollack-Wahl, J. "It is time to stand up and communicate". Proceedings 30th ASEE/IEEE Frontiers in Education Conference, Kansas City, USA, FIG-16-FIG-21. 2000.

Rees, C., \& Garrud, P. "Identifying undergraduate medical students' attitudes toward communication skills learning: A pilot study Medical Teacher" 23(4). https://doi.org/10.1080/01421590120057067. 2001. pp. 400-406.

Schulz, B. "The importance of soft skills: Education beyond academic knowledge. Journal of Language and Communication” 2(1). 2008. Pp.145-154.

Saravanan, V . "Sustainable Employability Skills for Engineering Professionals." The Indian Review of World Literature in English,5(2): 1- 9. 2009. Pp. 1-9.

Tanyel, F., \& Mitchell, M. The skill set for success of new business school graduates: Do perspective employers and university faculty agree? Journal of Education for Business, 75, https://doi.org/10.1080/08832329909598987. 1999. pp. 1999.

Dr. Dipakkumar A. Bhatt Assistant Professor (English), Science \& Humanities Department, Vishwakarma Government Engineering College, Opp. Sangath Mall, Gandhinagar-Visat Highway, Chandkheda, Ahmedabad, Gujarat. M- 9725129704, Email id-dipakbhattvgec@gmail.com 